\title{
The Irony Approach in the Qur'an: Mustansir Mir's Perspective
}

\author{
Azam \\ Universitas Islam Negeri (UIN) Sunan Kalijaga Yogyakarta \\ azamputramadura@gmail.com
}

\begin{abstract}
In the Qur'an interpretation, the irony approach is hardly ever used by commentators. Muntasir Mir is one of the commentators who used the irony approach in analyzing the. This paper then aims to explain Mir's thoughts in his article entitled "Irony in the Qur'an: a Study of the Story of Joseph. "In this article,heinterpreted the Qur'an by using the irony approach thatintroduced a new discourse to interpret the Qur'an for Muslims. Besides, Miraims to showthat theunderstanding of the Qur'an is not only stagnant in theological understanding. He invites Muslims to possess the beauty of literature contained in the Qur'an. Furthermore, Mir tried to illustrate the irony in the story of the Prophet Joseph. He described irony as an event beyond logic since it is a message fromGod. The Irony of the Prophet Joseph is a representation of humans' lousy plan that Allah changed to be good. It described the ambitious efforts of his brothers to destroy him by sending him to a well, but conversely, it took him to the peak of fame and power. And all the efforts to alienate the Prophet Joseph finally comes at His mercy.
\end{abstract}

Keywords: Irony, Qur'an, Muntasir Mir

\section{Introduction}

The Qur'an is believed to be the word of God. ${ }^{1}$ It is trusted to be a historical fact of the manifestation of kalamullah (Allah's words) that are authentic. ${ }^{2}$ Al-Qur'an in its capacity is the Book hidayah, tasyrik, and the constitution (dustur) in human life and opening the horizons in the universe, ${ }^{3}$ and shalih li kulli makan wa zaman. Scholars agree that the beautiful side of the

${ }^{1}$ Munzir Hitami, Pengantar Studi Al-Qur'an, Teori dan Pendekatan, (Yogyakarta: LkiS, 2012), page. 1.

${ }^{2}$ Fajar Riza Ul Haq, Membela Islam Membela Kemanusiaan, (Bandung: Mizan, 2017), page. 1.

${ }^{3}$ Adnan Muhammad Zarzur, Ulum al-Qur'an, Madhal ila al-Tafsir al-Qur'an wa Bayani Ikjazihi, (Beirut: Maktabah Islami), page. 13.

AJIS : Academic Journal of Islamic Studies, vol. 5, no. 1, 2020

IAIN Curup - Indonesia | ISSN 2580-3174, (p); 2580-3190 (e)

DOI: $10.29240 /$ ajis.v5i1.1318, page: $21-42$ 
language and the wording of the verses of the Qur'an are fascinating.4 Mustansir Mir also tried to present the story of the Prophet Joseph in the Qur'an with the Irony approach in its interpretation.

Mustansir Mir's approach has a new style in interpreting the Qur'an with different characteristics from the previous interpreters. ${ }^{5}$ In the journal "Irony Style in Teutra Atom Novels," it is stated that irony contains allusions in the form of using a word with the opposite meaning. ${ }^{6}$ Likewise, in the analysis of RahilHelmi in the article "Majesty Contained in the Qur'an Translation of AlBaqarah". Rahil generally described the figurative language in the form of affirmation such as pleonasm, comparison forms such as allegory, contradictory forms such as paradoxes, and syndromic forms such as irony. ${ }^{7}$ Since the text is a historical entity that is formed in certain situations and times surrounding its author, then an interpreter of the text has two positions and duties. One side as a historian who tries to return to historical meaning and another side as a philosopher who tries to find and create meaning. ${ }^{8}$ The application of this historical approach emphasizes the importance of the moral ideal of the Qur'an rather than specific legal provisions. ${ }^{9}$

Based on his analysis, Mustansir Mir found that the previous interpreters' interpretation was only dogma as if it were absolute truth with no gap for reinterpretation through a different approach. Whereas al-Qur'an is a book that has unlimited sides. Ay method or approach that has been used to study its meaning will never be enough. Therefore, the interpretation of the Qur'an does not stop from its birth to the present. In a variety of literature as

\footnotetext{
${ }^{4}$ Issa J. Boullata, Al-Qur'an Yang Menakjubkan, Bacaan Terpilih dan Tafsir Klasik hingga Moderen dari Seorang Ilmuan Katolik, (Jakarta: Lentera Hati, 2008), page. 3.

Interpretation is a set of knowledge to understand the words of Allah sent to the Prophet Muhammad PBUH, explain its meaning, draw the laws and lessons learned. As for the tools in Mufasir Mutaqaddimin's approach namely, Lughat Science, Nahwu Science, Sahrf Science, aya Middle Science n, Ushul al-Fiqh, Qira'at, Asbab al-Nuzul, dan Nasikh Mansukh. (Zarkasy, Al-Burhan fi Ulum al-Qur'an, (Al-Qahirah: Dar al-Turast), page. 13.

${ }^{6}$ Herman dkk, Analisis Gaya Ironi Dalam Novel Teuntra Atom Karya Thayeb Loh Angen, JIM PBSI, Vol, 3No, 3, 2018, page. 200.

${ }^{7}$ Rahil Helmi, Majas Yang terkandung dalam Al-Qur'an Terjemahan Surat AlBaqarah, (Seminar Nsional UNY, 2017), page. 475.

8 Syamsul Wathani, Paradigma Sintesi Tafsir Teks Al-Qur'an "Menimbang Hermeneutika Pemaknaan Teks Jorge. J.E Gracia Seabagai Teori Penafsiran Tekstual alQur'an", Journal of Qur'an and Hadith Studies, Vol. 5, No. 1, 2016, page.37.

${ }^{9}$ Asep Setiawan, Hermeneutika Al-Qur'an "Mahab Yogya" (Telaah atas Teori Ma'na-Cum-Magha dalam Penafsiran Al-Qur'an), Jurnal Studi Ilmu-Ilmu al-Qur'an dan Hadis, Vol . 17, No 1, 2016, page. 87-88.
} 
regards the Qur'an that has been written, the Qur'an has been interpreted with the methods of tahlili, ijmali, muqaran, and maudhui with approaches that include fiqh, philosophical, literary and social, Sufi, theological to science. ${ }^{10}$ Sahiron Syamsuddin divides three important things that are very significant in interpretation, namely (1) historical meaning (al-ma'na al-tarikhi), (2) phenomenal historical significance (al-magzha al-tarikhi), and (3) dynamic significance (al-magzha al-muharrik) for the context when the Qur'an is interpreted. 11

The concept of an interpretation is motivated by many things, including the background of the interpreter, interpreter's genealogy, the culture of the interpreter, interpreter's socio-political, and interpreter's point of view. In this case, Abdullah Saeed divides an interpretation at three levels, namely textual, semi-textual, and contextual. ${ }^{12}$ Furthermore, in the category of interpretation, Sahiron Syamsuddin divides the three streams of the Qur'an's interpretation viewed from the meaning. First, the conservative quasi-objectivist view. It is a view that the teachings of the Qur'an must be understood, interpreted, and applied today as the Qur'an was interpreted and applied to the era of the Prophet Muhammad PBUH and was delivered to the first generation (His friend). This interpretation view was followed by Muslims, such as the Ikhwanul Munslimin in Egypt and Salafis in several Islamic countries. Second, subjectivist view. This view asserts that an interpretation is entirely the subjectivity of the interpreter so that the truth is relative. Based on this reason, every generation has the right to interpret the Qur'an following the development of science and experience at the time the Qur'an is interpreted. This view was shared by Hasan Hanafi and Muhammad Syahrur. Third, a progressive quasi-objectivist view. This stream believes that interpreters in the

${ }^{10} \mathrm{Abu}$ Hay al-Farmawi, Al-Bidayah fi al-Tafsir al-Maudu'i, (Kairo:al-Hadarah alArabiyah, 977), page. 17.

${ }^{11}$ Sahiron Syamsuddin dkk, Pendekatan Ma'na-Kum-Magzha Atas Hadis AlQur'an Dan Hadis: Menjawab Problematika Sosial Keagamaan Di Era Kontemporer, (Yogyakarta: Asosiasi Alquran \& Tafsir se Indonesia, 2020), page. 8-9.

${ }^{12}$ First, textualists argue for strict following of the text and adopt a literal istic approach to the text. Yang kedua, semi-textuakist esensitally follow the textualists as far as lunguistic emhasis and ignoring sosio-historical context are concerned, but they pakcage the ethico-legal content in a samewhat 'modern' idiom, often within an apologetic discourse. Yang ketiga, contextualist emphasize the socio-historical context of the ethico-legal content in the Qur'an and of its subsequent interpreation. The argue for understanding the ithico-legal content in the light of the political, social, cultural, and economic contexts in which this content was revealed, iterpreted and applied. (Abdullah Saed, Interpreting The Qur'an Towards a Contemporary Approach, (London And New York: Taylor \& Francis Group), page. 3. 
millennial era are still obliged to explore the original meaning with the systematic tools of interpretation, as well as other interpretive instruments. It involves information about the macro-historical context of the Arab world when revelation, modern theories of linguistics and literature and hermeneutika. This view is embraced by Fazlur Rahman with the concept of double movement, Muhammadal-Thalibi with the concept of al-tafsir almaqasidi, (interpretation based on the primary purpose of law enforcement), and Nasr Hamid Abu Zayd with his concept of al-tafsir al-siyaqi (contextual interpretation). ${ }^{13}$

As regards the approaches reviewed by experts, the composition of the Qur'an has a fascinatingside and still has a unique background. Muslims who seriously examined that the Qur'an we read today were not arranged based on a chronology of the descent,but it based on a new arrangement. The order of Qur'an that consists of 114 surah was believed from the Prophet Muhammad PBUH. Moreover, some information stated that the arrangement is the result of ijtihad of friends (sahabat).14 As we have seen in the history of Ulum al-Qur'an, the mystery behind the composition of the Qur'an, it has invited Muslim scholars to conduct in-depth studies to produce knowledge known as muna>sabah which explores the relationship among verses in the surah, or between surah in the Qur'an.

Anchored in the above facts, asto respond to Mustansir Mir's statement, all approaches used in Qur'an interpretation have not been able to give serious attention to its arrangement. Some of the approaches also have not given significant consequences hermeneutically towards the Qur'an's arrangement. ${ }^{15}$ In this case, Mustansir Mir took a new approach to understanding the Qur'an. He provided a significant interpretation of irony's study.

\section{The Biography of Muntasir Mir}

Muntansir Mir is a Pakistani scholar. The figure who was born in 1949 completed his Bachelor of Arts (BA) and Master of Arts (MA) education at Punjab University (Lahore, Pakistan) in 967 and 1969. Mustansir Mir continued his master's study for the second time at the University of Mihigan

13Sahiron Syamsuddin dkk, Pendekatan Ma'na-Kum-Magzha Atas Hadis AlQur'an Dan Hadis: Menjawab Problematika Sosial Keagamaan Di Era Kontemporer,page. 3-6.

14Muhammad Husain al-Zahabi, al-Tafsir wa Mufassirun jilid II, (Kairo: Dar alKutub al-Hadisah, 1976), page. 496.

15Mustansir Mir, Coherence in the Qur'an: A Study of Islahi's Conep of Nazm in Tadabur-i Qur'an, (Washington: American Trust Publications, 1986), page. 3. 
(Ann Abror, Michigan, graduated in 1980). Mustansir Mir then continued his doctoral studies at the same university. In 1983, Mustansir Mir achieved the Doctor of Philosophy title with a dissertation entitled "Thematic and Structural Coherence in The Qur'an: A Study of Islah'sConceptibility of Nazm". ${ }^{16}$ Mustansir Mir was also actively taught on some campuses, such as Michingan Uneversity. Mustansir Mir served as an assistant professor of midwife Near Eastrem Studies for seven years (1986-1993). He taught at one of the universities in Lahore Pakistan (possibly in the Punjab University, his previous campus), the International Islamic University of Malaysia (IIUM), and Yungstown State University (YSU) which is located in the city of Younstown, the state of Ohio, United States. At Yungstown State University (YSU) Mustansir Mir taught Islamic Studies courses with a focus on Qur'anic Studies and Iqbal. In addition, he was also given the mandate of managing The Center for Islamic Studies (TCIS, the Center for Islamic Studies, structurally under the Department of Philosophy and Religious Studies). ${ }^{17}$

Besides being busy with teaching and managing TCIS activities, Mustansir Mir actively participates in academic-public activities both in the local ${ }^{18}$ and international community. ${ }^{19}$

${ }^{16}$ Ahmad Fathurrohman Dardiri, Bibel Sebagai Sumber Tafsir al-Qur'an (Studi Pemikiran Mustansir Mir dalam Understanding The Islamic Scripture: A Study of Selected Passages from The Qur'an), (Yoyakarta: Tesis UIN Sunan Kalijaga, 2015), page. 92.

${ }^{17}$ Ahmad Fathurrohman Dardiri, Bibel Sebagai Sumber Tafsir al-Qur'an (Studi Pemikiran Mustansir Mir dalam Understanding The Islamic Scripture: A Study of Selected Passages from The Qur'an), page. 92-93.

${ }^{18}$ Among the activities participated by Mustansir Mir in the local academic community are as follows. The first: The speaker at the terrorism discussion held by YSU after the September 11, 2001 tragedy, on October 18, 2001. The second: The speaker at the monotheistic religions discussion held by The Adult Education Coomitte of St. Michael Parish. The weekly activity during October 2001 invited many speakers. On October 15, Rabbi Simeon Kolko spoke about Judaism, October 22 Pat Manning spoke about Christianity, and October 29 Mustansir Mir about Islam. The third: Speaker at Howland Community Chruh on November 11, 2001, with the theme "Islam in The Ccontext of Current Conflicts ". Fourth: Speakers at a meeting with PPB representatives on the theme "Roots of Terrorism", held in Younggstown on January 24, 2002. The fifth: Recipients of awards in the field of Philoshopy and Religious Studies from the Distinguished Profeshorship Awards, on April 28, 2002. Sixth: Speaker main (Kynote Speaker) at the Islamic House of Socity of Greater Younstownpenhouse event on September 11, commemorating the September 11, 2001 tragedy. At the Kilcawley Center, August 13, 2003. The eighth: Leading the discussion entitled "Studying the Jewish Traditions: The Joseph Story". The YSU campus was held on February 13, 2006. The eight: Speakers at the Leaders Symposium post-series of 
Mustansir Mir has a religious view that there is truth in religion besides Islam. This view becomes the essential foundation for Mustansir Mir in assessing that both the Qur'an and the Bible have the same message content. This view was applied by Mustansir Mir in his work "Understanding The Islamic Scripture: A Study of Selected from the Qur'an" which explicitly cites the Bible as one of its sources. According to Mustansir Mir, quoting the Bible is no strange thing to the interpretive tradition. There were several classical and modern interpretations that quoted the Bible. However, the commentators were reluctant to formally show the need for the Bible as a source of reference for their works. ${ }^{20}$

Moreover, Mustansir Mir studied interreligius which was pioneered in 1988. He used the article "The Qur'an as Literature" that appreciated the literary masterpiece of the Bible and the Qur'an. Four years later (1992), based on the Qur' anic literary concept that he mastered, Mustansir Mir compared the types of the Qur'an dialogue and the Bible in the "Dialogue in The Qur'an" article. He also compared the irony in the story of the Prophet Joseph in both the Qur'an and the Bible that was written in"Irony in The Qur'an (2000)". Socially, Mustansir Mir was successful with his activities. While from the academic side, the two articles entitled "The Jewish and Christian Encounter with Modernity: Relevance for Muslims" and "Christian Perspectives and Science and Their Significance for Modern Muslim Thought" are proof that the academic side of Mustansir Mir runs in balance with his social activities. Both

drama shows and the "J.B." by Archibald MacLeish organized by the YSU Theater Department. Forum on April 7, 2006. The ninth: One of the speakers in a panel discussion titled "The Sacred: A Clahs about Civilitazion" which discusses the controversy of making caricatures of Muhammad, on April 19, 2006, at McDonough Museum. The tenth: Muntansir Mir was the speaker in the series YSU's fall 2007 lecture, with the theme "Understanding the Roots oh The Problems in the Middle East", on November 2, 2007. The eleventh: Speaker at the seminar titled "Studying the Jewish and Islamic Traditios: Conception of Evils", by YSU on April 10, 2008. Twelfth: Speaker at the YSU seminar entitled "Studying the Jewish and Islamic Traditions: Conceptive Justice", on September 30, 2009. Thirteenth: Speaker at the YSU general seminar entitled "Studying Judaic and Islamic Traditions: Wowen in Judaism and Islam ", on 10 February 2010. Fourteenth: Speaker of the Community Leture Series organized by CS Lewis Institute (CSLI). Public lecture with the theme "Are We Free and Does It Matter?" took place on March 21, 2014 at Butler Borth, Younstwons. Discusses the link between freewill (freedom of will) and determinism (limited will) in philosophy. (Ibid, pp. 9596).

19Ibid, page. 96-97.

${ }^{20}$ Ahmad Fathurrohman Dardiri, Bibel Sebagai Sumber Tafsir al-Qur'an (Studi Pemikiran Mustansir Mir dalam Understanding The Islamic Scripture: A Study of Selected Passages from The Qur'an), page. 97-98. 
articles are evidence of how Mustansir Mir respected the thoughts of Jews and Christians and made them a reference for Muslim communities. ${ }^{21}$

\section{The Social History of The Book and Sithemics in "Irony in The Qur'an: A Study of The Story of Joseph"}

According to Mustansir Mir, an appreciation of the current composition of the Qur'an, with its surah as units, has only received more attention in interpretive studies since the 20th century. Interpretations that use such prominent features are, for example, the works of Asraf' Ali Sanafi (186311943), Sayyid Qutub (1906-1966), Muhammad 'Izzati Darwaza (his work was published in 1962), Muhammad Husain Thabatabi (1903-1981), and Hamid alDin al-Farahi (1863-1930).

Appertaining to his analysis of the previous interpreters' works, Muntansir Mir found that most of them interpreted the Qur'an onlywith theological interpretation and considered as an absolute interpretation. It implies that there was no other styles of interpretation. Hence, Qur'an is feared by two aspects of literacy. Firstly, creating an appreciation, as if there was no new scope and an interpretation of literature depends on dogma, an unwanted prerequisite. Since infidels were challenged by the Qur'an, even they are not believers. Secondly, it is obscured by the beauty of the Qur'an which attempts to prove that the Qur'an cannot be matched or even predicted. This is evidence of many works that have been written to ensure al-Qur'an's literation, indicating that the Qur'an is proven to be genuinely incomparable. One of the standard texts on the easy acceptance of al-Qur'an is i'jaz al-Qur'an Abu Bakar Muhammad bin Thayyib al-Baqillani (950-1013). While the book presents theological doctrine with a discussion, there is an attempt to direct all the ability to describe it as offering a sharp analysis of and rhetorical aspects. ${ }^{22}$

Mustansir Mir said that studying the Qur'an should be appropriate and completed with its sacredness and its existence that remains the form of li kulli makan wa zaman. This discussion is focused on a single literary element, namely irony in the twelfth surah in al-Qur'an. It offers a small contribution to the fulfilment of the need. The law of God which was once treated as a test on the Prophet Joseph contained five discussions. The first, summarizing the story

\footnotetext{
${ }^{21}$ Ahmad Fathurrohman Dardiri, Bibel Sebagai Sumber Tafsir al-Qur'an (Studi Pemikiran Mustansir Mir dalam Understanding The Islamic Scripture: A Study of Selected Passages from The Qur'an),page. 126-127.

${ }^{22}$ Mustansir Mir,Irony in the Qur'an: A Study of the Story of Joseph, (Issa J. Boullata, ed. Literary Structures oh Religi Meaning in The Qur'an. Curzon Studies in The Qur'an Richmond, Surrey, UK: Curzon, 2000. 173-1187, Chapter 8), page. 173.
} 
of the Prophet Joseph that has been told in the Qur'an (Part I summarizes the story in the Joseph in the Qur'an). The second, quoting and checking statements found in selected interpretations that work on irony in surah (Part II cites and examines comments found in selected interpretations works about irony in the surah). The third, analyzing the story of the Qur'an (Part III is analyzing the Qur' anic story). The fourth, comparing the irony version of the Qur'an with stories in the Bible. (Part IV compare, from the standpoint of irony, the Qur'an's version of the story the Biblical). The fifth, state the conclusion in learning (Part V states the conclusions of the study).23

\section{The Implication of Irony in The Qur'an From Munstansir Mir's Perspective}

This part discussesirony in the Qur'an and the Bible from the perspective of Mustansir Mir. It also discusses the history of Joseph in the Qur'an and the Bible. Before presenting the story of the Prophet Joseph, it is essential to know what irony is and its implications in the Qur'an and the Bible. The irony in the Indonesian Big Dictionary (KBBI) defines as"an event or situation that is contrary to the expected or supposed thing to occur, but has become a destiny". So it can be said that Irony is a drama or an event that occurs out of logic because it becomes a fate from God. Then the question arises about what are the implications of irony from the perspective of Mustansir Mir. Thus, the writer will outline Mustansir Mir' view about irony in the story of Joseph. Mustansir Mir put irony as follows: ${ }^{24}$

1. If the Prophet Joseph were discouraged after being thrown into a well, his fear would be proven. He would be judged to have no commitment and courage to continue his goals and dreams of his ancestors.

2. Potiphar (Aziz) refused to believe his wife's accusations against the Prophet Joseph. He immediately realized that the fault was with his wife. ${ }^{25}$ Then he rebuked Prophet Joseph and asked him to forget the whole incident. But just as Prophet Joseph felt he had been acquitted, he was sent to prison. In a series of times when the Prophet Joseph was seduced by Potiphar's wife, he saw the power of God so that he can survive from the

\footnotetext{
${ }^{23}$ Ibid, page. 173-174.

${ }^{24}$ Mustansir Mir, Irony in the Qur'an: A Study of the Story of Joseph, page. 178179

(نيو/قعها) with her. Then she closed the door and invited Joseph to copulate her. There are some opinions that there are seven doors locked by Aziz's wife. (Qurtubi, (Qurtubi, Al-Jami' Li Ahkam al-Qur'an, Jilid XI, (Beirut: Dar al-Fikr), page. 305-306.
} 
deceit. Among the power of God that happened to Prophet Joseph was the presence of his mother Rahel, her aunt Leah and her father Ya'qub, then the presence of his master. ${ }^{26}$

3. The Prophet Joseph was proficient in interpreting exciting dreams. ${ }^{27} \mathrm{He}$ was able to interpret his fellow prisoners' dreams correctly. He can also give the interpretation of the king's dream of saving Egypt from economic collapse. It is undeniable that the Qur'an aimed to prove that the miracle existed in the Prophet Joseph to interpret dreams is a gift from God, where he cannot look into his future. However, some Irony is still attached to the fact that people who help prevent evilness cannot see what is happening in his future.

This event began with a dream of eleven stars, one sun and one month prostrate to the Prophet Joseph. The Prophet Joseph understood that his dream was an indication showing that he was a particular person chosen by Allah. The Prophet Jacob, his father, then asked him not to tell his dreams to his brothers because they would be very jealous of him. Meanwhile, his brothers planned to get rid of the Prophet Joseph. They asked permission for the Prophet Jacob to allow Prophet Yusuf to go with them for a walk. Afterwards, they threw the Prophet Joseph into the well. To the Prophet Jacob, they created a false story about the death of the Prophet Yusuf. They brought some false evidence to strengthen their argument. However, the Prophet Ya'qub did not believe them. ${ }^{28}$

His brothers' deception about the Prophet Joseph required his father not to be sad. ${ }^{29}$ Although the Prophet Joseph was deceitfully thrown into a well, his brothers told their father that the Prophet Joseph was eaten by a wolf. Some of them said: "Do not kill Joseph", according to Qatadah, namely Rubil, said: "Do not kill Joseph, because killing is a bi sin". ${ }^{30}$ Actually, they did this badness due to they were not willing to see Allah's gift to the Prophet Joseph. It

26Eve Woogen, The Best Of Stories: Yusuf as Hebrew Translation of The Qur'an, (Tn.p, 2012), page. 48.

${ }^{27}$ According to Al-Maturidi, "Allah taught the Prophet Yusuf to ta'wilsuhuf that happen in the Prophet Ibrahim and other, and also God taught how to ta'wilsuhuf and events that will occur". (Abu Muhammad bin Muhammad Mahmud al-Maturidi, Ta'wilatu Ahlissunah, Tafsir al-Maturidi, Jilid VI, (Beirut: Dar al-Kutul al-Ilmiyah), page. 209.

28Muhammad Rustom, The Qur'nic Story Joseph as a "Of The Human Soul", PriPrint Version; Forthoming in Mahreb Review, page. 2.

${ }^{29}$ Mustansir Mir,Irony in the Qur'an: A Study of the Story of Joseph, page. 174.

30Muhammad Nawai al-Jawi, Marah Labid Li-Kaysfi Makn al-Qur'an al-Majid, (Surabaya: Dar al-Ulum), page. 393. 
was the reason underlying the Prophet Jacob to prevent the Prophet Joseph to tell his dreams to his brothers. ${ }^{31}$

The Prophet Jacob tried to remind the Prophet Joseph about what his brothers might do to him.By seeing such a situation, the Prophet Jacob finally did not believe the Prophet Joseph's brothers. ${ }^{32}$ In the end, the Prophet Jacob patiently accepted what had happened. His brothers believed that as soon as Joseph came out of Jacob's view, he would immediately come out of Jacob's mind (verse 9) "yakhlu lakum wajhu abikum" (You will get executive attention from Father,). As we have seen, their hopes turned out financially. Here we will note that there is a possible irony in the use of the word wajh, "face" in verse (9). As a result of his deep sadness over Joseph's disappearance, the Prophet Jacob lost his sight and therefore could not see the brothers. Instead of turning his face towards them, he spoke, turning completely away from them, as if he could not even see them. That was the thought of the Prophet Joseph that was worth seeing. Surprisingly, the Prophet Jacob regained his eyesight only when he took Joseph's robe and believed he would meet him again. Previously, after leaving the Prophet Joseph in the wilderness, the brothers returned to Jacob and lied to him about Joseph. ${ }^{33}$

Given this situation, the Prophet Joseph's brothers saw that their father did not believe them. They said: "You will not believe us even if we tell the truth". It implies irony in two senses. First "wa law kunna sadiqin" (even if we tell the truth). As such, these are non-committed statements made by people with an anxious conscience, and may be followed by words that are not expressed: "And we know we are not telling the truth". Thus an ironic comment on the report they gave to the Prophet Joseph. Second, this verse is proleptic. When, in a letter, they explained to the Prophet Jacob why they failed to bring Benjamin back from Egypt, the brothers, to their knowledge, told the truth (verses. 1-2). Still, the Prophet Jacob did not want to believe them, ironically a statement "You will not trust us even if we tell the truth".34

The essence Irony of the Prophet Joseph's journey can be concluded in a statement: "evil intended by humans turns out to be good by God". The Joseph' brothersput much efforts to send the Prophet Joseph to be forgotten.

\footnotetext{
${ }^{31}$ Fuad AL-Aris, Pelajaran Hidup Surah Yusuf, Yang Tersirat dan Yang Memikat dari Kisah Hidup Nabi Yusuf a.s, (Jakarta: Zaman, 2005), page. 29.

${ }^{32}$ Fuad AL-Aris, Pelajaran Hidup Surah Yusuf, Yang Tersirat dan Yang Memikat dari Kisah Hidup Nabi Yusuf a.s,page. 29-30.

${ }^{33}$ Mustansir Mir,Irony in the Qur'an: A Study of the Story of Joseph, page. 180

${ }^{34}$ Mustansir Mir,Irony in the Qur'an: A Study of the Story of Joseph, page. 181.
} 
Nevertheless, it became a means of lifting him to the peak of fame and power. Also, all the conspiracies to get rid of the Prophet Joseph eventually became His mercy. In Kanaan, the Prophet Joseph was thrown into an Egyptian pit in prison. The first event was due to the hatred of his brothers towards him, and the second event was from Potiphar's wife towards the Prophet Joseph. ${ }^{35}$

From the journey of the Prophet Joseph and his brothers, it appears to be an Irony who's right and wrong. God will never be wrong in judging, and His will is always dominant. ${ }^{36}$ In the sense that the Prophet Joseph did not have a loser character. The Prophet Joseph who was abandoned became the ruler of Egypt, a ruler who filled with the sadness of the Prophet Jacob, in order to gain his lost sight and be proud of a jealous brother who finally saw the light. Finally, the story means that the Irony of the Prophet Joseph is not tragic. Still, irony has pushed a few lessons, short lessons spoken verbally in the letter but sufficiently illustrated by developing the story. Both of these lessons can be quoted as follows: "God did not leave them and God gave it all to those who make mistakes as an opportunity to correct their mistakes (brothers of the Prophet Joseph)".37

In the thesis that evil intended by humans to be good by God, in this story there is an Irony that is opposed in another thesis story: "That innocence sometimes comes inappropriate damage even though ultimately the damage gives way to goodness". But the next thesis is overshadowed in the first story, and both of them are resolved into mastering the thesis that is, which is the primary control of God, inevitably fulfils its purpose. The Word of God: "Take full control of his affairs, but most people do not know." (Sura Yusuf verse 21). 38

\footnotetext{
35Mustansir Mir, The Muslim World, The Qur'anic Of Joseph: Plot, Themes Characters, No. I, Vol. LXXVI, Januari 1986, page. 3.

36That God is dominant and alaways fulfills His purproses is a therme that is not peculiar to joseph but isexpresest in many other place in the Qur'an. Whats is peculiart to joseph is the which the theme is brought hom-thorugh a sustainrd use irony. (Issa J. Boullata, ed. Literary Structures oh Religi Meaning in The Qur'an. Curzon Studies in The Qur'an Richmond, Surrey, UK: Curzon, 2000. (Irony in the Qur'an: A Study of the Story of Joseph: Mustansir Mir), page. 177.

37Mustansir Mir,Irony in the Qur'an: A Study of the Story of Joseph, page. 177.

${ }^{38}$ Mustansir Mir, Irony in the Qur'an: A Study of the Story of Joseph, page. 176177.
} 


\section{The Styles and Methods of Mustansir Mir's Perspective in "Irony In The Qur'an: A Study of The Story Joseph"}

Mapping the types of the typology of thought in the interpretation of the Qur'an is aimed at making it easier to distinguish between the features and characteristics of each interpretation of the Qur'an being studied. Hence, in the discourse of contemporary Islamic thought, hermeneutic discourse becomes one solution to the impasse of Islamic methodology seems to be something that is necessary. Contemporary thinkers such as Arkoun, Nasr Abu Zaid, Hasan Hanafi, Amina Wadud-Muhsin, Fatima Mernessi, Muhammad Shahrur, and other figures often allude to this method. ${ }^{39}$

Muhammad Husein al-Zahabi put forward seven trends that develop in the realm of interpretations. It includes the Interpretation of bi al-Ma'tsur, Interpretation of bi al-Ra'yi, Interpretation of Sufis, Interpretation of Fiqh, Interpretation of Falsafi, Interpretation of Ilmi and Interpretation of Adabi and Ijtima'i. ${ }^{40}$

According to the writer's analysis, in his presentation Mustansir Mir is more inclined to the realm of Tafsir $a l-R a^{\prime} y i$. He prefers rationality to the meaning of the birth of the text itself. Then it can be said that Mustansir Mir has a new style or method of interpretation, and from the new method (contemporary). The method of reading texts is that he directs the interpreter to not only aware of what is stated in the text and how to speak it, but also to be aware of what is not stated in the text and how it is silenced. ${ }^{41}$

In the development of Qur'an interpretation time by time, the term interpretation style has been familiar, and it variesdependson the expertise and tendencies of the mufassir themselves. Every commentator commonly has specific fields in interpreting the Qur'an according to the background of his knowledge so that various patterns of interpretation exist. Qur'an is the words of Allah and is an indisputable fact that all Muslims throughout the world read and recite in Arabic.It is unique throughout history and always varies in interpretation. 42

${ }^{39}$ M. Nur Zuhdi, Pasaraya Tafsir Indonesia dari Kontestasi Metodologi hingga Kontekstualisasi, (Yogyakarta: Kaukaba Dipantara), page. 23-24.

40 Muhammad Husain al-Zahabi, al-Tafsir wa Mufassirun, Jilid 1, (Beirut: Turast, 1976), page. 20.

41 Muhammad Abed al-Jabiri, Formasi Nalar Arab Kritik Tradisi dan Wacana Agama, (Jogjakarta: IRCiSoD, 2014), page. 99.

42 Inggid Mattson, Ulumul Qur'an Zaman kita Pengantar untuk Memahami Konteks, Kisah, dan Sejarah al-Qur'an, (Jakarta: Zaman, 2016), page. 203. 
As regards the methods applied in interpreting the Qur'an, NashruddinBaidan in his book, mentioned that there are four methods developed by interpretive scholars. They are the global method (al-manhaj alijmali), analytical method (al-manhaj al-tahlili), the comparative method (almanhaj al-muqaran), and the thematic method (al-manhaj al-mawdhu'i).43

According to these four methods, it can be seen what method Mustansir Mir used in his interpretation. As far as the writers' observations, Mustansir Mir is more inclined to use analytical and comparative methods (Tahlili and almanhaj al-muqaran), it can be analyzed from the following example:

"The relationship of Joseph with his father and his brothers conceived in the Qur'an is very differently than it is in the Bible. In Genesis, Jacob, while he must know about the brothers' hatred of Joseph, does not seem to entertain seriously the possibility that the brothers would try to harm Joseph. In the Qur'an, on the other hand, the brothers do not enjoy the trust of Jacob. Accordingly, while in Genesis Jacob can send Joseph in search of the brothers (37:13-14), the incident would have been out of place in the Qur'an and so does not occur I it all. As we saw, Jacob in the Qur'an has a keen theoretical premonition that Joseph's brothers might do him harm, which becomes ironic when, in actual practice, Jacob is found to be incapable of warding misfortune off from Joseph. The character of the Qur' anic Jacob, it would appear, is somewhat more complex than that of the Biblical-for one thing, he is less credulous- and this makes for pungent irony in the Qur' anic incidents involving him". ${ }^{4}$

\footnotetext{
${ }^{43}$ Nashruddin Baidan, Metode Penafsiran Al-Qur'an (Yogyakarta: Pustaka Pelajar, 2002), page. 17.

${ }^{44}$ Joseph's relationship with his father and brothers understood in the Qur'an is very different from what is in the Bible. In the event, although Jacob had known about Joseph's brothers' hatred towards him, he did not seem to show seriously the possibility that the brothers would really try to hurt Joseph. On the Qur'an, on the other hand, his brothers do not enjoy Jacob's trust. Thus, while in Genesis Jacob could send Joseph to look for his brothers (37: 13-14), the incident was out of place in the Qur'an and therefore did not occur at all. As we have seen, Jacob in the Qur'an has a sharp theoretical premonition that his brothers Joseph might hurt him, which becomes ironic when in actual practice, Jacob is found unable to ward off the bad luck of Joseph. Jacob's Qur'anic character somewhat seems more complex than that of the Bible for one thing, he is less credible and this makes a sharp irony in the Qur'anic incident involving him. (Mustansir Mir, Irony in the Qur'an: A Study of the Story of Joseph), page. 183.
} 
The text above indicates the character of the Prophet Jacob and his sharp analysis of something that will happen to his son (Joseph), where his brothers will hurt him. Mustansir Mir, in this part, compared the interpretation of the Qur'an with the Bible. Accordingly, "the accurateness of the Prophet Jacob analysis towards what would occur to Joseph" in the Qur'an seems more complicated than in the Bible. It is also following the interpretation of Sheikh al-Thusi. When the Prophet Jacob said:" how painful my heart is due to my separation from Joseph", indicated that this incident was news from God about the Prophet Jacob when he was looking for Joseph's brothers to ensure Joseph's safety and save him from their guile. 45

\section{The Comparison of Mustansir Mir's Interpretation of The Qur'an and Bibel in "Irony in The Qur'an: A Study of The Story Joseph"}

The Qur'an is a divine revelation came with miracles. Without intense attention, people can assume that many similarities in some verses of the Qur'an are only a repetition of editors. For this reason, the presence of the method of interpreting verses that have the same or similar editorial is very useful.

Appertaining to the comparative method used by Mustansir Mir in interpreting, the question arises as regards the way he compared the interpretation between the Qur'an and the Bible. Before coming to the discussion, it is necessary to explain the notion of comparison (muqaran). Nasruddin Baidan explained that it is an activity of comparing the text of the Qur'an's verses that have the similar editorin two or more cases, have a different meaning for the same case, compare the verses of the Qur'an with the hadiths that seems contradictive since its presence, and compare various commentators' opinions. ${ }^{46}$ Editorial differences give a signal about the mental state and mind of mukhatab on the presentation of an interpretation ${ }^{47}$. Since the Qur'an has lots of vocabulary (mufradat) and meaning, the chosen word can respond to various changes in situation, space, and time, and produce

\footnotetext{
${ }^{45} \mathrm{Abu}$ Ja'far Muhammad bin Hasan al-Thusi, Al-Tibyan fi Tafsir al-Qur'an, Jilid VI, (Bairut: Daru Ihyau al-Turast al-Arabi), page. 107.

46Nasruddin Baidan, Metode Penafsiran Al-Qur'an, (Yogyakarta: Pustaka Pelajar, 2002), page. 65.

${ }^{47}$ M. Quraish Shihab, Kaidah Tafsir, Syarat, Ketentuan, dan Aturan yang Patut Anda Ketahui dalam Memahami Ayat-Ayat Al-Qur'an, (Jakarta: Lentera Hati, 2013), page. 383.
} 
various interpretations. ${ }^{48}$ Thus, it is no wonder if there is a difference in interpretation because the Qur'an is universal. ${ }^{49}$

The contextualization of the Qur'an expects interpreters to keep in mind the hierarchical nature of the values found in every Qur'anic text. In the contextualization process is an attempt to determine the same level of significance. One of the most challenging issues in the contextualization process is the effort to determine the level of significance that should be placed on the specific Qur'anic values that have been identified in the text under study. ${ }^{50}$ The Qur'an will always be interpreted, and that interpretation will not reduce the holiness of the Qur'an itself. Muntasir Mir, regarding this point, made two observations on the attempted interpretation of Muslims in the story of the Prophet Joseph in the Qur'an:

1. There is no doubt that some Qur'anic commentaries note the presence of Irony elements in the story of the Prophet Joseph. A good example is the following Qurtubi reading: commenting on frase wallahu ghalibun ala amrihi (and God is in full control of his affairs-God's will always prevail). Imam Qurtubi writes:

“The wise man'swordstowards this verse: (God holds full control of his will). Although the Prophet Jacob told his son Joseph not to confuse his dreams to his brothers, God's will always prevail. Therefore, theirony happened beyond reason to the Prophet Joseph towards his dream. Then his brothers planned to kill the Prophet Joseph, but God's will always prevail even when the Prophet Joseph became the king they bowed to the Prophet Joseph. Then his brothers hoped to secure attention for their father, but God's will always prevail, so that their fathers' hearts became shy to them and even after seventy or eighty years the Prophet Jacob thought and said: unfortunately only for Joseph!. Then they thought to be good (after

${ }^{48}$ When the Qur'an reaches the hands of Man, the truth of that religion has become an interpretation, and the interpretation does not exist except that it has no imperfections when compared with the original religion of God. This imperfection can take two forms. First, a human interpretation can be sure to contain the potential for error, and it can be ascertained not free from error, and secondly, the truth that humans capture from God, although it may be true, is partial.(Haidar Baqir, Islam Tuhan Islam Manusia, Agama dan Spiritualitas di Zaman Kacau, (Bandung: Mizan, 2019), page. 10-11.

${ }^{49}$ Muchlis M. Hanafi, Moderasi Islam, Menangkal Radikalisasi Berbasis Agama, (Pisangan Ciputat: Ikatan Alumni Al-Azhar dan PSQ), page. 156.

${ }^{50}$ Abdullah Saeed, Al-Qur'an Abad 21, Tafsir Kontekstual, (Bandung: Mizan, 2016), page. 109. 
evacuating the Prophet Joseph),and that was their repentance. Still, God's will always prevail, they forgot their sin persisted in it after seven years had passed, they made an acceptance (their mistake), previously, the Prophet Joseph, said to their father: "Indeed we made a mistake". 51

2. In some cases,as regards the Prophet Joseph Irony's interpretation, it seems that it does not exist in the Qur'anic text. However,it existoutside the Qur'anic text, precisely in the below andit refers to the text.

The starting point for the dramatic conflict in the story is the Prophet Jacob's love for Joseph, or more precisely, his brothers' perceptions of love who thought that the Prophet Jacob's love was only for Joseph. The Qur'an seems to indicate that the Prophet's feeling for Joseph was based on recognition of his extraordinary talent. ${ }^{52} \mathrm{He}$ was very sensitive to losing his charisma because of the sadness of losing Joseph. 53

The journey and irony of the Prophet Joseph from time to time were not only about the conflicts between the brothers but also the past event outside his family. Among them is responding tohis two prison friends' feeling. They were amazed and liked the Prophet Joseph. For the trauma or irony that had happened to him, the Prophet Joseph begged them to forget their feeling. In this point, Mustansir Mir interpreted the irony that happened to the Prophet Joseph as clear as possible. The Prophet Joseph responded to his prison friends who liked him like what was written in the following:

"I implore you, in God's, not to love me! For, by God, not one person ever loved me without my suffering some kind of misfortune on account of his love. My aunt loved me, and I suffered misfortune on account of her love. My father loved me, and I suffered misfortune on account of his love. Then

51Mustansir Mir,Irony in the Qur'an: A Study of the Story of Joseph, page.175

52The Prophet Jacob felt that, among all his sons, only Joseph was qualified to carry on the tradition of Abraham after he was confirmed in his views after he dreamed of the Prophet Joseph.(Mustansir Mir, The Muslim World, The Qur'anic of Joseph: Plot, Themes Characters), page. 13.

53The Prophet Jacob did not believe the news of the death of Prophet Yusuf from his brothers. It can be combined that the Prophet Jacob is the ideal of destiny and tadbir: unlimited belief in God, does not become a barrier for him from the dangers that will come. But when his prevention failed, he brought misfortune by shouting his heart to God. (Mustansir Mir, The Muslim World, The Qur'anic Of Joseph: Plot, Themes Characters), page. 13. 
the wife of my master loved me, and I suffered misfortune on account of her love. So do not love me, may God bless you!".54

Grounded on the above text, it describes the journey of the Prophet Joseph and Irony happened to him. Mustansir Mir then compared the story of Joseph in the Qur'an and the Bible. The text above indicates that the Prophet Joseph forbade whoever to like him due to the misfortune that had happened, and the irony was out of logic.

Mustansir Mir revealed and compared the differences between what statedin the Qur'an and what stated in the Bible. One of his interpretation in both the Qur'an and the Bible is the Qur'an illustrates that Joseph's brothers previously made planning (before removing the Prophet Joseph), while in the Bible it was done spontaneously, without any prior planning. From the following passage, we can see how Mustansir Mir illustrates it in the text:

"Major difference in the plot is that in the Bible, the brother's attempt to dispose of Joseph is spontaneous whereas in the Qur'an it is premeditated. In Genesis, since the conspiracy is hatched on the spur of the moment and away from home, Jacob has left out of the picture altogether. In Genesis the brothers take advantage of Jacob's ignorance, in the Qur'an the use the method of deception: to put a smooth face on the conspiracy, they seek Jacob's approval to take Joseph out on a picnic. This difference between the two versions results in some twists of irony that are peculiar to the Qur'an. The Qur'ani>c incident involving Benjamin's travel to Egypt, for example, may be taken to be a rich ironic replication of the similar incident involving Joseph, related earlier in the sura. The same cannot perhaps be said of the corresponding Genesis incident involving Benjamin's travel to Egypt".55

${ }^{54}$ I ask you in the name of God so that no one likes me, nothing without suffering such as misfortune because of love. My aunt loves me and I suffer in misfortune. Then my father loved me and I suffered because of his love. Then my master's wife loved me and I suffered in misfortune. So don't love me, may God bless you. (Mustansir Mir,Irony in the Qur'an: A Study of the Story of Joseph), page. 176.

${ }^{55}$ The main difference in the plot of story is that in the Bible the brother's attempt to remove Joseph spontaneously whereas in the Qur'an it was planned beforehand. In Genesis, because the conspiracy was moved suddenly and away from home, Jacob was not included at all. In Genesis, the brothers took advantage of Jacob's ignorance, in the Qur'an using a deceptive method: to make a smooth face at the plot, they sought Jacob's approval to take Joseph out on a picnic. The differences between these two versions produce some irony that is specific to the Qur'ran. The Qur'anic incident involving Benjamin's trip to Egypt, for example, can be considered as a rich 
In another text Mustansir Mir also illustrates the difference between the text of the Bible and the text in the Qur'an. One of the texts in the Bible, that the hatred of his brothers Joseph, because the Prophet Joseph brought bad reports to his father. However, in the Qur'an this is not the case. The Qur'an illustrates that the Prophet Jacob who forbade his son Joseph from telling his dreams to his brothers, because the Prophet Ya'qub knew about Joseph's dream ta'wil, and Prophet Ya'qub was worried that Joseph would tell his brothers his brothers, but Joseph's brothers understood about his dream ta'wil, so they had jealousy and envy towards Joseph. ${ }^{56}$ Why did Joseph's brothers envy Joseph? It was because they understood about the ta'wilof Joseph's dream where Joseph would be God's chosen people. ${ }^{57}$ Then it becomes clear that Mustansir Mir compared the interpretation of the story in the Qur'an and the Bible. It revealed that in his interpretation Mustansir Mir is not solely in the context of interaction with the Qur'an, but also interacts with the Bible. ${ }^{58}$ Comparison of the two we can see the presentation of Mustansir Mir in the text, namely:

"In the Bible one of the reasons given for the brothers' hatred of Joseph is that "Joseph brought an ill report of them to their father" (Gen.37:2). The Qur'an does not contain any mention of this; it presents Joseph as a completely innocent person who falls victim to the sheer malevolence of his brothers. Now if, according to Bible, Joseph used to bring Jacob evil reports about his brothers, then even though it would in no way justify the brothers' cruel treatment of him, the brothers' hostility toward him would become somewhat understandable, especially if Joseph used to indulge in that reprehensible habit very often. This would seem to blunt slightly the edge of the irony".59

ironic replication of a similar incident involving Joseph, which was related earlier in the sura. The same thing might not be said about the corresponding incidents involving Benjamin's trip to Egypt. (Mustansir Mir, Irony in the Qur'an: A Study of the Story of Joseph), page. 182.

${ }^{56}$ Syaukani, Fathul Qadir, Al-Jamik baina fannirriwa>yat wa al-Dira>yah fi 'Ilm al-Tafsir, Jilid III, (di tahkik dan hadisnya di takhrij oleh Dr. Abd al-Raman Umairah), page. 7.

${ }^{57}$ Allah will make you the chosen man "Joseph". (1) bow to you "Josephf" and be given the level of prophethood, (2) his brothers are not appointed as Prophets from the beginning or the end, because a Prophet will not plan to kill Muslims. (Qurtubi, AlJami' Li Ahkam al-Qur'an, (Beirut: Da>r al-Fikr), pages. 128-133.

58Islah Gusmian, Tafsir Al-Qur'an Kekuasaan Di Indonesia, Peneguhan, Konteks dan Pertarungan Wacana, (Yogyakarta: Salwa, 2019), page. 24.

${ }^{59}$ In the Bible one of the reasons given for the brothers' hatred toward Joseph is that "Joseph brought a bad report about them to their father" (Genesis 37: 2). The 
Resting upon the above text, it is clearly seen that Mustansir Mir compared the journey of the Prophet Joseph and his brothers. According to Mustansir Mir, it was clearly seen the hatred of Joseph's brothers. Due to false lousy news to the Prophet Jacob, it brought disaster to the hatred of his brothers towards Joseph. However, in the Qur'an, it is not the same description of the text. The Prophet Jacob reminded Joseph not to tell his dreams to his brothers because of fear that there was an unfortunate irony on the Prophet Joseph, although irony happened out of their logic.

From the interpretation of Mustansir Mir above, there is a different interpretation about the story of Joseph's journey. It can be from of Imam Suyuti's interpretation who stated that it was not Joseph who brought a bad report to his father, but it caused byhis brothers spiteful towards Joseph. Imam Suyuti narrated from Ibn Jarir and Ibn Abi Ha the team from Suda said that "The Prophet Jacob landed in Sham, there was no purpose except Joseph and Bunyamin, so Joseph's brothers was jealous and envious because they feel the Prophet Jacob's love was only for Joseph.60 This also strengthened the interpretation of al-Alusi. He indicated that it was not Joseph who brought a bad report to his father, because it is impossible for a Prophet to bring a false report or a hoax. However, Mustansir Mir is not firm in responding to this. It is a very clear interpretation of al-Alusi that Joseph is God's chosen person. God completed His favours on Joseph as God gave His favours on two previous fathers, namely Ibrahim and Ishak. ${ }^{61}$

\section{Conclusion}

Mustansir Mir, in his presentation about the study of irony in the Qur'an, revealed an interpretation that is rarely done among other commentators. Then it was concluded that Mustansir Mir was a very neutral person. He interpreted the Qur'an with the Bible, quoted from previous scholars, and compared the Qur'an with the Bible in an interpretation. One of

Qur'an does not mention this; it presented Joseph as the truly innocent person who was the victim of the crime of his brothers. Now, if according to the Bible, Joseph used to bring evil reports to Jacob about his brothers, so even if that would justify his brothers 'cruel treatment of him, the brothers' hostility towards him would be somewhat understandable, especially if Joseph used to enjoy this despicable habit very often. This seems to gather a little bit of the tip of irony.(Mustansir Mir,Irony in the Qur'an: A Study of the Story of Joseph), page. 183.

60Jalaluddial-Suyuti, Durr al-Mantsur fi al-Tafsir bi al-Ma'tsur, Jilid VIII, (Qahirah: Markaz Lilbuhust Waddirasah al-Arabiyah wa al-Islamiyah), page. 186.

61Mahmud al-Alusi, Rauh al-Ma'ani, Tafsir al-Qur'an al-Adzim wa Sab'i alMasta>ni, (Beirut: Ihya'u al-Turast al-Arabi), page. 188. 
his findings of the irony of the Prophet Joseph's journey in the Qur'an is thatMustansir firmly said that the Prophet Joseph's brothers were jealous tohim since they heard the news about the Prophet Joseph dreaming about eleven stars and the sun. It was because the dream implied that the Prophet Joseph would become king and became the successor to the religion of Ibrahim. Conversely, in the Bible, the Prophet Joseph was the one who brought a false report on his father, so they hate the Prophet Joseph. Mustansir Mir is a very progressive interpreter. One example illustrated the irony of the Prophet Joseph is a journey that is not in accordance with the will of the Prophet Joseph but has become God's choice and became God's drama to increase the degree of the Prophet Joseph.

\section{References}

Abed al-Jabiri, Muhammad, Formasi Nalar Arab Kritik Tradisi dan Wacana Agama, (Jogjakarta: IRCiSoD, 2014).

Al-Alusi, Mahmud, Rauh al-Ma'ani, Tafsir al-Qur'an al-Adzim wa Sab'i alMastani, Jilid XII, (Beirut: Ihya'u al-Turast al-Arabi).

AL-Aris, Fuad, Pelajaran Hidup Surah Yusuf, Yang Tersirat dan Yang Memikat dari Kisah Hidup Nabi Yusuf a.s, (Jakarta: Zaman, 2005).

Al-Farmawi, Abu Hay, Al-Bidayah fi al-Tafsir al-Maudu'i, (Kairo: al-Hadarah alArabiyah, 977).

Andopa, A., Hardivizon, H., \& Yunita, N. (2018). The Meaning of Nafs in the Qur'an Based on Quraish Shihab's Interpretation. AJIS: Academic Journal of Islamic Studies, 3(2), 139-162. doi: http://dx.doi.org/10.29240/ajis.v3i2.578

Baidan, Nashruddin, Metode Penafsiran Al-Qur'an (Yogyakarta: Pustaka Pelajar, 2002).

Baqir, Haidar, Islam Tuhan Islam Manusia, Agama dan Spiritualitas di Zaman Kacau, (Bandung: Mizan, 2019).

Fathurrohman Dardiri, Ahmad, Bibel Sebagai SumberTafsir al-Qur'an (Studi Pemikiran Mustansir Mir dalam Understanding The Islamic. Scripture: A Study of Selected Passages from The Qur'an), (Yoyakarta: Tesis UIN Sunan Kalijaga, 2015).

Gusmian, Islah, Tafsir Al-Qur'an Kekuasaan Di Indonesia, Peneguhan, Konteks dan Pertarungan Wacana, (Yogyakarta: Salwa, 2019).

Hasan al-Thusi, Abu Ja'far Muhammad bin, Al-Tibyan fi Tafsir al-Qur'an, Jilid VI, (Beirut: Daru Ihyau al-Turast al-Arabi).

Helmi, Rahil, Majas Yang terkandung dalam Al-Qur'an Terjemahan Surat Al- 
Baqarah, (Seminar Nsional UNY, 2017).

Herman dkk, Analisis Gaya Ironi Dalam Novel Teuntra Atom Karya Thayeb Loh Angen, JIM PBSI, Vol, 3No, 3, 2018.

Hitami, Munzir, Pengantar Studi Al-Qur'an, Teori dan Pendekatan, (Yogyakarta: LkiS, 2012).

Husain Zahabi, Muhammad, al-Tafsir wa Mufassirun jilid II, (Kairo: Dar alKutub al-Hadisah, 1976).

J. Boullata, Issa, Al-Qur'an Yang Menakjubkan, Bacaan Terpilih dan Tafsir Klasik hingga Moderen dari Seorang Ilmuan Katolik, (Jakarta: Lentera Hati, 2008).

Kisworo, B., \& Hardivizon, H. (2020). Telaah Leksikal, Gramatikal, dan Kontekstual Terhadap Makna Kata Syahida pada QS. al-Baqarah ayat 185. AL QUDS : Jurnal Studi Alquran dan Hadis, 4(1), 163-180. doi:http://dx.doi.org/10.29240/alquds.v4i1.1473

M. Hanafi, Muchlis, Moderasi Islam, Menangkal Radikalisasi Berbasis Agama, (Pisangan Ciputat: Ikatan Alumni Al-Azhar dan PSQ).

Mattson, Inggid, Ulumul Qur'an Zaman kita Pengantar untuk Memahami Konteks, Kisah, dan Sejarah al-Qur'an, (Jakarta: Zaman, 2016).

Mir, Mustansir, Irony in the Qur'an: A Study of the Story of Joseph, Issa J. Boullata, ed. Literary Structures of Religi Meaning in The Qur'an. Curzon Studies in The Qur'an Richmond, Surrey, UK: Curzon, 2000. 173-1187, Chapter 8).

Mir, Mustansir, Coherence in the Qur'an: A Study of Islahi'sConep of Nazm in Tadabur-i Qur'an, (Washington: American Trust Publications, 1986).

The Muslim World, The Qur'anic of Joseph: Plot, Themes Characters).

Muhammad Mahmud al-Maturidi, Abu Muhammad bin, Ta'wilatu Ahlissunah, Tafsir al-Maturidi, Jilid VI, (Beirut: Dar al-Kutul al-Ilmiyah).

Naf'atu Fina, Lien Iffah, Pre-Canonical Reading of The Qur'an (Studi atas Metode Angelika Neuwirth dalam Analais Teks al-Qur'an Berbasis Surat dan Intertektualitas), (Yoyakarta: Tesis UIN SunanKalijaga, 2011).

Nawawi al-Jawi, Muhammad, Marah Labid Li-Kaysfi Makn al-Qur'an al-Majid, (Surabaya: Dar al-Ulum).

Qurtubi, Al-Jami' Li Ahkam al-Qur'an, (Beirut: Dar al-Fikr).

Rustom, Muhammad, The Qur'anic Story Joseph as a “Of The Human Soul”, PrePrint Version; Forthoming in Mahreb Review. 
Saed, Abdullah, Interpreting The Qur'an Towards a Contemporary Approach, (London And New York: Taylor \& Francis Group).

Saeed, Abdullah, Al-Qur'an Abad 21, Tafsir Kontekstual, (Bandung: Mizan, 2016).

Setiawan, Asep, "Hermeneutika Al-Qur'an "Mazhab Yogya" (Telaah atas Teori Ma'na-Cum-Magha dalam Penafsiran Al-Qur'an)", Jurnal Studi Ilmu-Ilmu al-Qur'an dan Hadis, Vol . 17, No 1, 2016.

Shihab, M. Quraish, Kaidah Tafsir, Syarat, Ketentuan, danAturan yang Patut Anda Ketahui dalam Memahami Ayat-Ayat Al-Qur'an, (Jakarta: Lentera Hati, 2013).

Suyuti, Jalaluddin, Durr al-Mantsur fi Tafsir bi Ma'tsur, Jilid VIII, (Qahirah: Markaz Lilbuhust Waddirasah al-Arabiyah wa al-Islamiyah).

Syamsuddin, Sahiron dkk, Pendekatan Ma'na-Kum-Magzha Atas Hadis AlQur'an Dan Hadis: Menjawab Problematika Sosial Keagamaan Di Era Kontemporer, (Yogyakarta: Asosiasi Alquran \& Tafsir se Indonesia, 2020).

Syaukani, Fathul Qadir Al-Jamik baina fanniyirriwayat wa al-Dirayah fi 'Ilm alTafsir, Jilid III, (di tahkik dan hadisnya di takhrij oleh Dr. Abd al-Raman Umairah).

Ul Haq, Fajar Riza, Membela Islam Membela Kemanusiaan, (Bandung: Mizan, 2017).

Wathani, Syamsul, Paradigma Sintesi Tafsir Teks Al-Qur'an "Menimbang Hermeneutika Pemaknaan Teks Jorge. J.E Gracia Sebagai Teori Penafsiran Tekstual al-Qur'an", Journal of Qur'an and Hadith Studies, Vol. 5, No. 1, 2016.

Woogen, Eve, The Best Of Stories: Yusuf as Hebrew Translation of The Qur'an, (Tn.p, 2012).

Zarkasy, Al-Burhan fi Ulum al-Qur'an, (Al-Qahirah: Dar al-Turast).

Zarzur, Adnan Muhammad, Ulum al-Qur'an, Madhalila al-Tafsir al-Qur'an wa Bayani Ikjazihi, (Beirut: Maktabah Islami).

Zuhdi, M. Nur, Pasaraya Tafsir Indonesia dari Kontestasi Metodologi hingga Kontekstualisasi, (Yogyakarta: Kaukaba Dipantara). 